\title{
OLAHRAGA GATEBALL BAGI USIA LANJUT
}

\section{Oleh: Yudik Prasetyo}

Dosen Jurusan Pendidikan Kesehatan dan Rekreasi FIK-UNY

\begin{abstract}
Abstrak
Program pembinaan usia lanjut dapat melalui olahraga, salah satunya dengan melakukan olahraga gateball. Gateball adalah jenis olahraga dengan menggunakan tongkat pemukul bola (stick), dan dimainkan oleh 2 (dua) tim saling berhadapan. Peranan gateball saat ini semakin besar, negara dengan populasi lanjut usia sudah menjadi problem nyata, tetapi gateball dapat menjadi sumber kebahagian seumur hidup untuk orang usia lanjut.

Usia lanjut adalah mereka yang berusia 55 tahun ke atas. Keberhasilan mencapai kebugaran usia lanjut ditentukan oleh takaran latihan yaitu FIT (Frekuensi, Intensitas, dan Time). Olahraga gateball yang dilakukan oleh usia lanjut dilakukan 3 kali per minggu, intensitas antara 60-75\% detak jantung maksimal, dan waktu yang diperlukan dalam satu game 30 menit. Olah raga gateball termasuk olahraga yang sederhana, namun bermanfaat luar biasa. Dengan melakukan olahraga gateball dapat bermanfaat melatih daya tahan otot lengan, daya tahan otot kaki, koordinasi, serta daya tahan aerobik (daya tahan paru jantung).
\end{abstract}

Kata kunci: gateball, usia lanjut

Sehat tidak hanya milik usia muda, saat usia senja kesehatan juga harus dijaga. Bukan hanya masalah panjang usia, namun yang terpenting adalah panjang usia yang sehat, bebas dari penyakit. Seperti diketahui bahwa saat usia bertambah, penyakit degeneratif, seperti stroke, demensia, sakit jantung, sakit ginjal, sakit tulang, dan sendi mulai mengintai. Sehingga pentinglah bagi seorang usia lanjut untuk mempertahankan kebugaran fisiknya. Saat fisik bugar penyakitpun terhindar (Yuda Turana, 2011: http://www.medikaholistik.com).

Salah satu tolak ukur kemajuan suatu bangsa seringkali dilihat dari angka harapan hidup penduduknya. Indonesia sebagai salah satu negara berkembang, memiliki angka harapan hidup penduduk yang semakin meningkat sejalan dengan meningkatnya taraf hidup dan pelayanan kesehatan kepada masyarakat. Peningkatan jumlah orang usia lanjut di Indonesia diperkirakan antara tahun 1990-2025 sebesar $414 \%$. Kondisi ini akan menempatkan Indonesia pada urutan ke-3 yang memiliki populasi usia lanjut terbanyak di dunia pada tahun 2020, setelah Cina dan India. (Emma, S. Wirakusumah, 2002 : 1). Hal ini dapat menimbulkan masalah sosial khususnya menyangkut masalah kesehatan dan kesejahteraan hidup warga usia lanjut apabila tidak ditangani dengan baik.

Dalam program pembinaan usia lanjut dapat melalui olahraga. Olahraga yang sering dilakukan oleh para usia lanjut untuk memelihara dan meningkatkan kebugaran seperti 


\section{MEDIKORA Vol. VIII, No 2 April 2012}

bersepeda, senam aerobik maupun jalan kaki atau joging. Kegiatan yang dilakukan para usia lanjut seharusnya bervariasi, sehingga tidak cepat bosan. Sebenarnya ada olahraga yang sifatnya ringan seperti golf dapat dilakukan, tetapi biaya yang dikeluarkan mahal. Untuk mengantisipasi hal tersebut, diperlukan pemilihan olahraga yang tepat bagi usia lanjut yaitu olahraga yang ringan, mudah dilakukan, dan menarik. Dengan melakukan aktifitas fisik berupa latihan yang dapat mencukupi kebutuhan oksigen yang diperlukan pada waktu kerja atau latihan, maka diharapkan dapat memelihara dan meningkatkan kebugaran jasmani, karena oksigen tidak dapat di simpan sebagai persediaan dalam tubuh. Oleh sebab itu, yang dapat dilakukan adalah menjaga dan meningkat kemampuan organ-organ tubuh yang berfungsi menyerap dan menyalurkan oksigen agar selalu dalam kondisi baik. Latihan ini sifatnya aerobik, dalam hal ini salah satu latihan yang cocok untuk usia lanjut adalah latihan gateball.

Gateball adalah olahraga dengan menggunakan tongkat pemukul dan bola. Sebagai salah satu jenis olahraga permainan, gateball telah menjadi olahraga yang mulai popular di Indonesia. Berbagai jenis olahraga dinikmati di seluruh dunia. Namun, tidak banyak yang menggabungkan antara kompetisi dan sebagai hiburan bagi semua orang baik tua maupun muda. Gateball dapat dinikmati oleh laki-laki maupun peremuan dari semua generasi, oleh karena itu gateball disebut juga olahraga tanpa batas (barrier-free sport).

Ada beberapa komponen yang mempengaruhi tingkat kebugaran jasmani yaitu daya tahan paru jantung, daya tahan otot, kekuatan, power, kelentukan, dan kecepatan. Komponen dalam kebugaran jasmani sangat diperlukan dalam kegiatan yang membutuhkan kondisi fisik yang bagus. Karena komponen - komponen itu sangat bergantung pada kondisi fisik seseorang. Dalam latihan gateball juga mengandung dari komponen kebugaran tersebut, seperti saat memukul bola, dan mengumpan bola.

\section{SEJARAH GATEBALL}

Gateball atau bola gawang adalah jenis olahraga dengan menggunakan tongkat pemukul bola (stick) dan dimainkan oleh dua tim saling berhadapan (Suryanto, 2011). Gateball ditemukan pada tahun 1947 di kota kecil Memuro, di Hokkaido, Jepang. Eiji Suzuki adalah pencipta olahraga populer ini. Di tengah-tengah kekacauan setelah Perang Dunia II, ingin memberi sesuatu yang sederhana untuk anak-anak miskin yang tidak mempunyai mainan. Olahraga baru ini, diilhami dari permainan barat "croquet" (permainan bola kayu), sejak itu gateball menyebar di sluruh Jepang (http://gateball. Wordpress.com/ history/). 


\section{MEDIKORA Vol. VIII, No 2 April 2012}

Gateball dimainkan sangat mirip kroket tapi lebih cepat, diperkenalkan ke Hong Kong pada 1986. Hampir dua puluh tahun kemudian, permainan gateball telah semakin populer dan sekarang dimainkan oleh lebih dari delapan ratus orang lanjut usia secara teratur (Eva Tsai, Lena Fung, dan Pinky Tso, 2005). Gateball kini telah dapat dinikmati di seluruh dunia berkat usaha dan promosi emigran Jepang, pemerintah, penggemar dan pabrikan olah raga. Begitu pula telah tersebar melalui pertukaran antar organisasi dan tour yang diorganisir oleh agen perjalanan untuk memperkenalkan olahraga ini ke luar negeri. Sesungguhnya, saat ini gateball dimainkan di lebih 30 negara dan daerah oleh lebih dari 10 juta orang. Semakin hari penggemarnya semakin meningkat.

Peranan permainan gateball saat ini semakin besar. Contohnya, pada banyak negara, populasi usia lanjut sudah menjadi problem nyata, tetapi gateball dapat menjadi sumber kebahagiaan seumur hidup untuk orang yang usia lanjut. Lebih dari itu, gateball memberi suatu kontribusi penting bagi pengembangan persahabatan internasional antar manusia, melebihi batasan nasional dan perbedaan budaya. Inilah suatu kontribusi yang terus meningkat bagi masyarakat global.

Gateball masa kini adalah suatu jenis olahraga yang dapat dimainkan dengan mudah, di manapun berada dan dengan siapapun. Perhimpunan gateball dunia berharap dapat memper-kenalkan atraksi olahraga internasional yang santai ini dan membantu mereka memahami potensi masa depannya.

Di Indonesia, gateball dikelompokkan dalam kategori olah raga rekreasi dan bukan olah raga prestasi. Pembinaannya bukan oleh KONI, tetapi oleh FORMI (Federasi Olahraga Rekreasi Masyarakat Indonesia). Secara nasional, gateball memiliki wadah bernama Pergatsi (Persatuan Gateball Seluruh Indonesia) yang didirikan tahun lalu dengan ketua umum pertamanya Djoko Kirmanto yang juga menjabat Menteri Pekerjaan Umum. Di level internasional, olahraga ini di bawah naungan Perhimpunan Gateball Dunia (World Gateball Union/WGU) yang diketuai Jepang, tempat kelahiran gateball (Ruslan Burhani, http://www.antaratv.com).

\section{Fasilitas dan Alat Bermain}

\section{a. Lapangan}

Lapangan berbentuk persegi panjang berukuran panjang 20-25 meter dan lebar 1520 meter. Lapangan dikelilingi oleh garis dalam (inside line) dan garis luar (outside line), dimana kedua garis tersebut berjarak antara 50-100 centimeter. Lebar garis dalam 


\section{MEDIKORA Vol. VIII, No 2 April 2012}

seharusnya 5 centimeter sedangkan garis luar lebarnya bervariasi yang penting jelas terlihat. Kedua garis sebaiknya berwarna kontras dengan warna lapangan (http:/gateball.wordpress.com/ equipment/lapangan).

Garis antara pojok (corner) pertama dan kedua disebut garis pertama, antara pojok kedua dan ketiga disebut garis kedua, antara pojok ketiga dan keempat disebut garis ketiga dan antara keempat dan pertama disebut garis keempat. Area start berbentuk persegi panjang yang terletak antara sisi luar garis keempat dan sisi luar garis luar dengan jarak 1 meter dan 3 meter dari pojok pertama kearah pojok keempat.

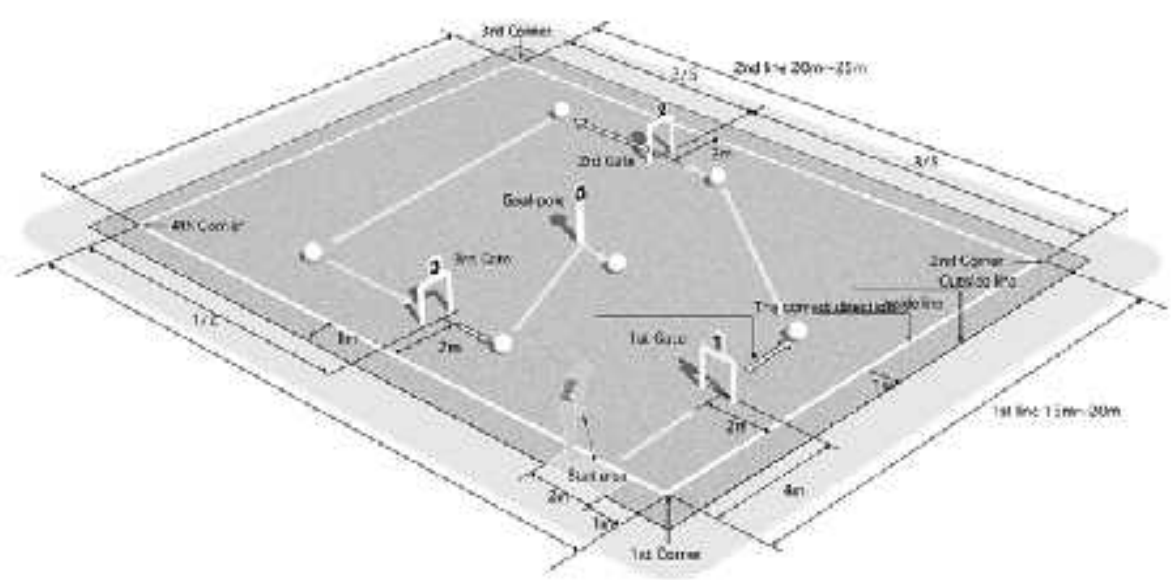

Gambar 1. Lapangan Gateball

(Sumber: http://gateball.wordpress.com/ equipment/lapangan)

\section{b. Tongkat Pemukul}

Tongkat pemukul berbentuk seperti huruf $\mathrm{T}$ yang terdiri atas bagian kepala dan batang. Bagian kepala berbentuk silinder dengan panjang antara 18-24 sentimeter dan berdiameter 3,5-5 centimeter. Sedangkan bagian batang tongkat panjangnya 50 sentimeter atau lebih yang terpasang pada bagian tengah kepala. Tidak ada batasan mengenai bahan dari tongkat ini, biasanya dapat terbuat dari logam ataupun kayu (http://gateball.wordpress.com /equipment/ tongkat-pemukul/).

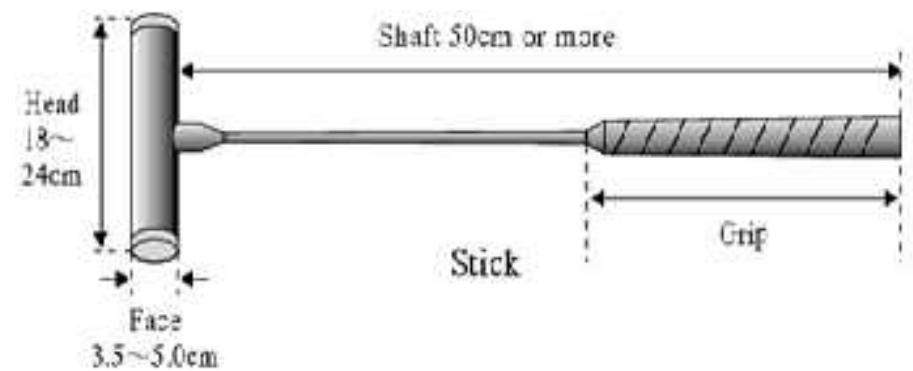


Gambar 2. Tongkat Pemukul

(Sumber: http://gateball.wordpress.com/equipment/tongkat-pemukul/)

\section{c. Bola}

Bola berdiameter 7,5 centimeter, mempunyai berat 230 gram dan terbuat dari resin sintetik. Terdapat 10 buah bola masing-masing lima berwarna merah dan lima berwarna putih. Bola merah bernomor ganjil yaitu 1, 3, 5, 7 dan 9, sedangkan bola putih bernomor genap yaitu 2, 4, 6, 8 dan 10 (http://gateball.wordpress.com/equipment/bola2/).

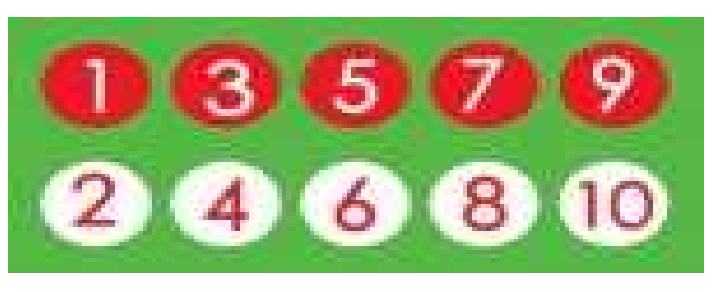

Gambar 3. Bola

(Sumber: http://gateball.wordpress.com/equipment/bola-2/)

\section{d. Gate}

Gate atau gawang meliputi gawang pertama, kedua dan ketiga. Gawang merupakan perlengkapan utama di samping stick, bola dan goal pole. Untuk memperoleh poin tiap bola harus melewati gawang secara berurutan. Gawang ditancapkan vertikal diatas lapangan, terbuat dari batang silinder dengan diameter $1 \mathrm{~cm}$ yang terdiri atas dua sudut sebesar $90^{\circ}$ dengan lebar $22 \mathrm{~cm}$ dan tinggi $19 \mathrm{~cm}$ dari permukaan lapangan. Tiap gawang diberi label sesuai nomor gawang. Label diletakkan pada puncak gawang berbentuk bujur sangkar dengan panjang tiap sisi $10 \mathrm{~cm}$ (http://gateball. wordpress.com/equipment/gate/).

Adapun letak gawang adalah sebagai berikut :

1. Titik tengah gawang pertama terletak 4 meter dari titik tengah area start menuju garis kedua dan sejajar dengan garis keempat.

2. Titik tengah gawang kedua terletak 2 meter dari garis kedua, tegak lurus pada titik $3 / 5$ dari pojok kedua menuju pojok ketiga dan ditancapkan sejajar garis pertama.

3. Titik tengah gawang ketiga terletak 2 meter dari titik tengah garis keempat dan sejajar dengan garis pertama. 


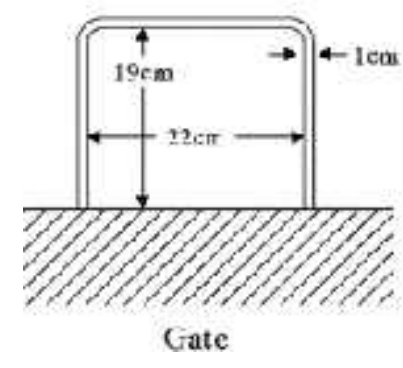

Gambar 4. Gate

(Sumber: http://gateball.wordpress.com/equipment/gate/)

\section{e. Pole}

Goal pole adalah suatu tiang yang diletakkan pada titik pusat lapangan. Gunanya selain untuk memperoleh poin setelah melewati ketiga gawang juga untuk mengakhiri permainan bagi bola tersebut. Biasanya terbuat dari pipa besi dengan diameter 2 centimeter, ditancapkan vertikal dengan tinggi 20 centimeter dari permukaan lapangan. Goal pole sebaiknya berwarna kontras dengan warna lapangan agar mudah dilihat (http://gateball.wordpress.com/equipment/pole/).

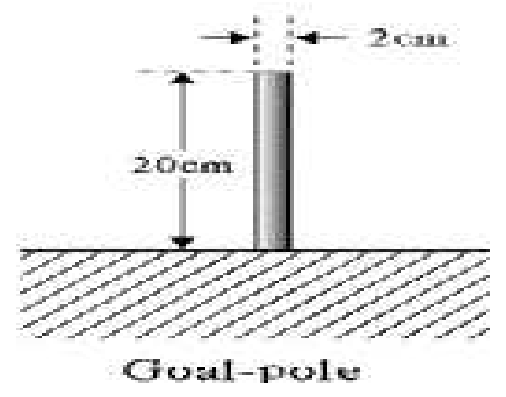

Gambar 5. Pole

\section{Peraturan Permainan Gateball}

(Sumber: http://gateball.wordpress.com/equipment/pole/)

Dimainkan oleh dua tim yaitu tim merah dan tim putih, dimana masing-masing tim terdiri atas 5 pemain. Tim merah memegang bola ganjil $(1,3,5,7,9)$ sedangkan tim putih memegang bola genap $(2,4,6,8,10)$. Tim merah memukul bola terlebih dahulu lalu diikuti team putih sesuai urutan nomor bola. Bola dipukul melewati 3 gawang (gawang 1 sampai 3) dan menyelesaikan permainan bila telah menyentuh goal-pole. Pemenang ditentukan oleh jumlah total nilai yang diperoleh selama 30 menit waktu permainan (http://gateball.wordpress.com/cara-main/). 


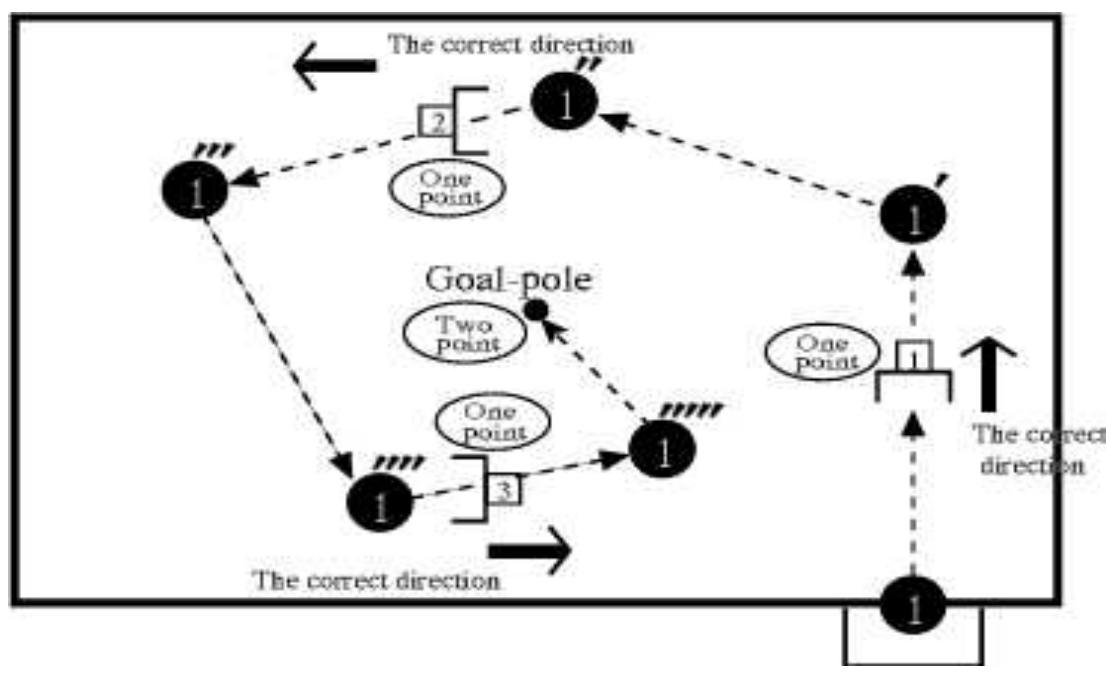

Gambar 6. Cara Bermain

(Sumber: http://gateball.wordpress.com/cara-main/)

Tiap tim terdiri atas 5 pemain inti dan pemain cadangan samapi 3 orang, salah seorang pemain bertindak menjadi kapten tim. Masing-msing tim memiliki seorang manajer.

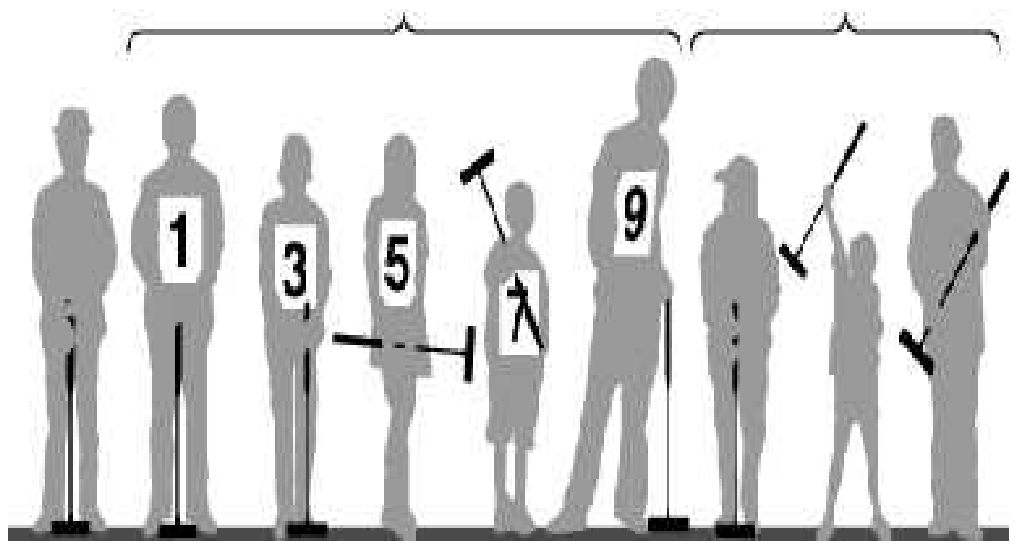

Gambar 7. Susunan Tim

(Sumber: http://gateball.wordpress.com/cara-main/)

Bola diletakkan pada area start, lalu dipukul sampai melewati gate pertama. Bila gagal, bola dikembalikan dan pemain tidak punya kesempatan memukul lagi, namun apabila berhasil, pemain mempunyai kesempatan satu kali lagi memukul bola. Bola tidak diijinkan masuk lapangan bila gagal melewati gate pertama.

Pemukulan yang sah adalah pemukulan terhadap bola sendiri setelah dipanggil wasit pada gilirannya, dengan menggunakan permukaan kepala tongkat pemukul, tepat mengenai bola. Dalam satu ayunan, walaupun stick mengenai sepatu, tanah atau benda lain, namun tongkat pemukul masih mengenai bola, pemukulan dianggap sah (suryanto, 2011: 23). 

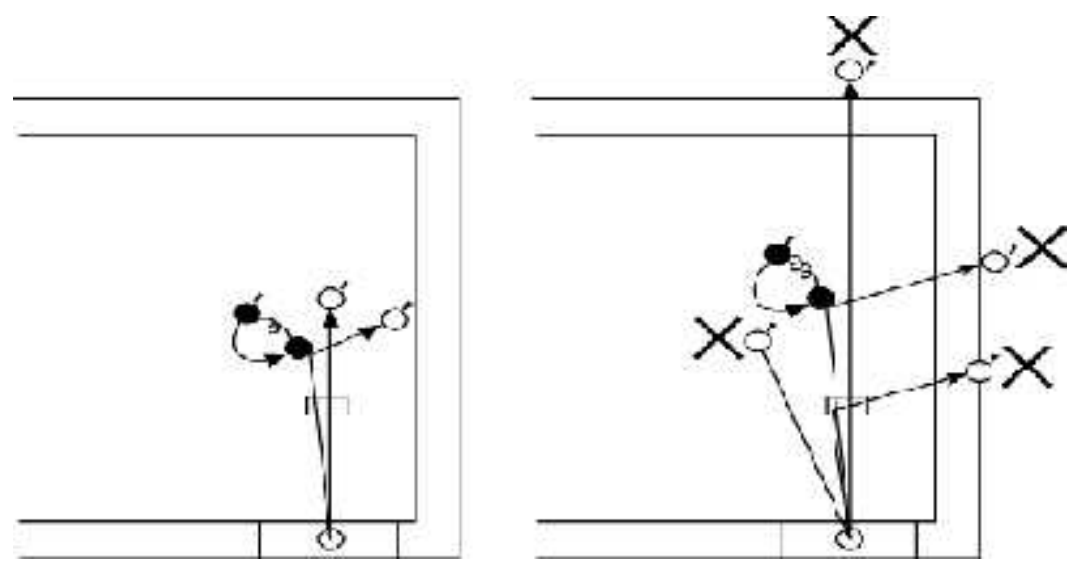

Gambar 8. Pukulan Pertama

(Sumber: http://gateball.wordpress.com/cara-main/)

Disebut out ball, jika hasil pukulan atau spark menyebabkan bola keluar dari garis lapangan. Jika pada kesempatan memukul berikutnya, bola yang keluar tadi dipukul masuk ke lapangan mengenai bola lainnya dalam lapangan, hal ini merupakan pelanggaran. Jika bola tersebut melewati gate atau goal-pole, bola tersebut tidak memperoleh poin.

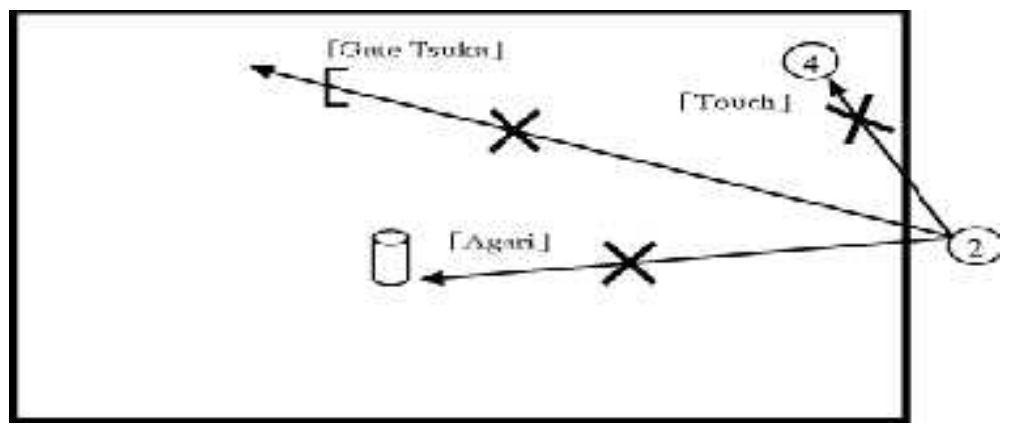

Gambar 9. Out Ball

(Sumber: http://gateball.wordpress.com/cara-main/)

Apakah touch? Ketika bola yang dipukul oleh pemain menyentuh atau mengenai bola lainnya (baik bola kawan maupun bola lawan), maka hal itu disebut "touch". Bila kedua bola masih dalam garis permainan maka pemain mempunyai kesempatan melakukan sparking. 


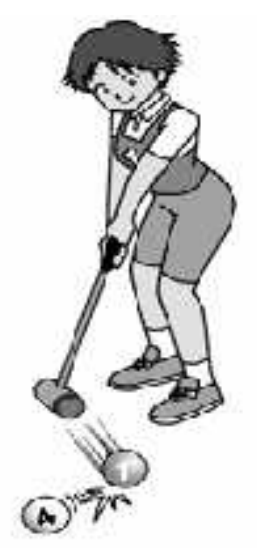

Gambar 9. Touch

(Sumber: http://gateball.wordpress.com/cara-main/)

Bagaimana melakukan sparking? Ambil bola yang tersentuh, injak bola di tempatnya berhenti kemudian letakkan bola yang tersentuh tadi menempel pada bolamu dan arahkan sesuai dengan keinginan. Kemudian pukul bolanya sehingga hanya bola yang tersentuh tadi yang bergerak lalu angkat kaki dari bolamu. Sparking yang sukses memberikan kesempatan memukul satu kali lagi. Ketika melakukan sparking, dengan mempertimbangkan strategi permainan, bola yang tersentuh dapat diarahkan ke tempat yang menguntungkan team. Misalnya, bila bola kawan yang di-sparking bola diarahkan melewati gawang untuk memperoleh poin namun bila bola lawan, bola tersebut dapat disparking bola keluar dari garis permainan.
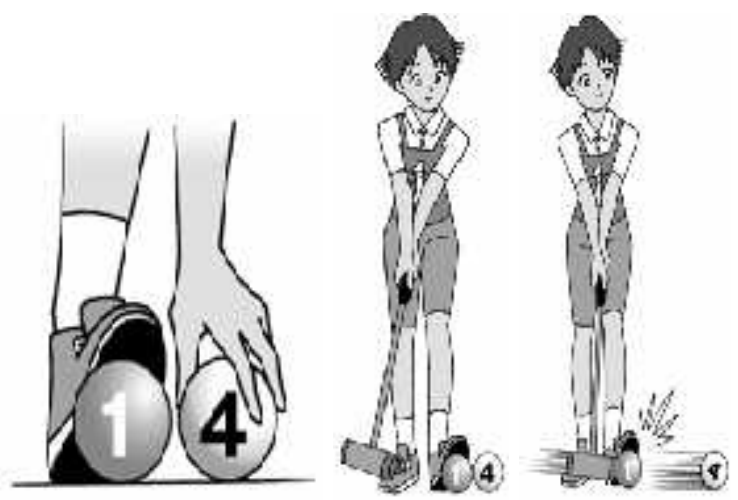

Gambar 10. Sparking

(Sumber: http://gateball.wordpress.com/cara-main/)

Mengumpan, yaitu menempatkan bola pada posisi yang relevan untuk pemain berikutnya. Lihat diagram di bawah, pemain team merah bola 1 memukul bola sampai terletak antara bola 3 dan bola 5. Harapannya bola 3 mengenai bola 1 lalu melakukan sparking ke arah yang menguntungkan sekaligus memangkas jarak antara bola 3 dan 5 menjadi lebih dekat sehingga lebih memungkinkn menyentuh bola 5 (http://gateball.wordpress.com/cara-main/). 


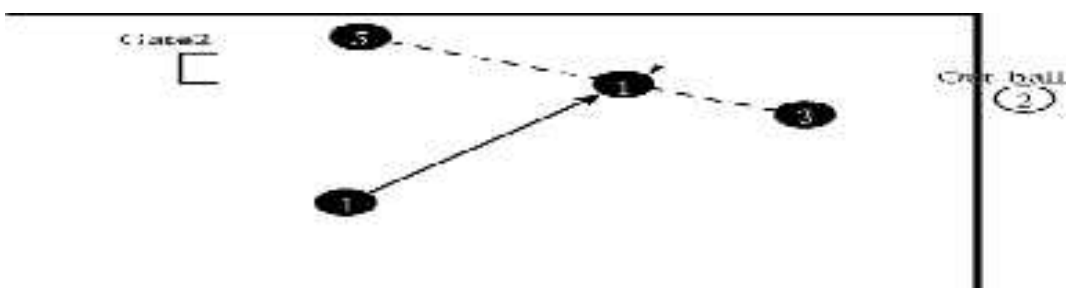

Gambar 11. Ketrampilan Tim

(Sumber: http://gateball.wordpress.com/cara-main/)

Sparking untuk mengirim bola kawan ke posisi yang menguntungkan untuk pemukul berikutnya. Lihat diagram di bawah, bola merah 1 mengenai bola 5 lalu dengan sparking mengirim bola 5 ke dekat bola 3. Bola 1 masih punya kesempatan memukul dan melanjutkan permainan. Namun ingat posisi bola 2 agar tidak membahayakan bola 3 .

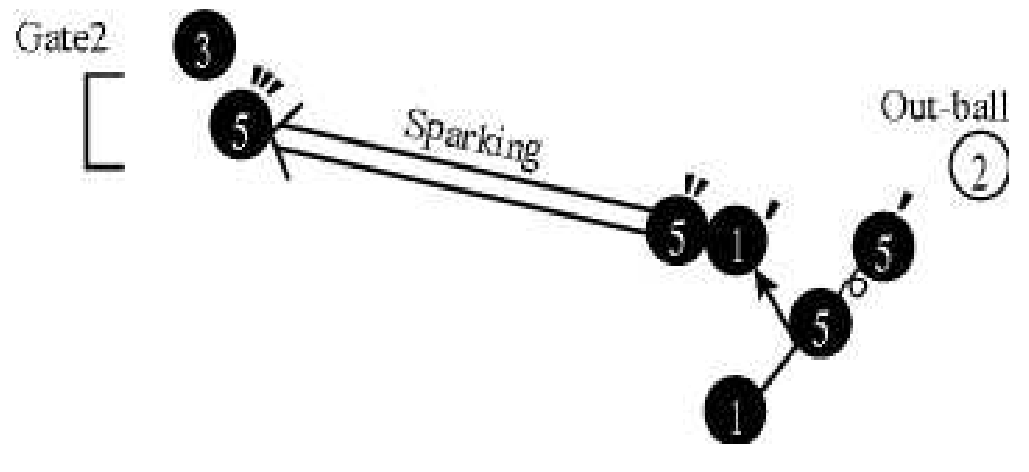

Gambar 12. Sparking dan Out Ball

(Sumber: http://gateball.wordpress.com/cara-main/)

Bila bola yang dipukul mampu melewati gawang (gate tsuka) sekaligus menyentuh bola setelah melewati gawang, bola tersebut mempunyai dua kali kesempatan memukul setelah berhasil melakukan sparking yang benar. Lihat diagram di bawah.

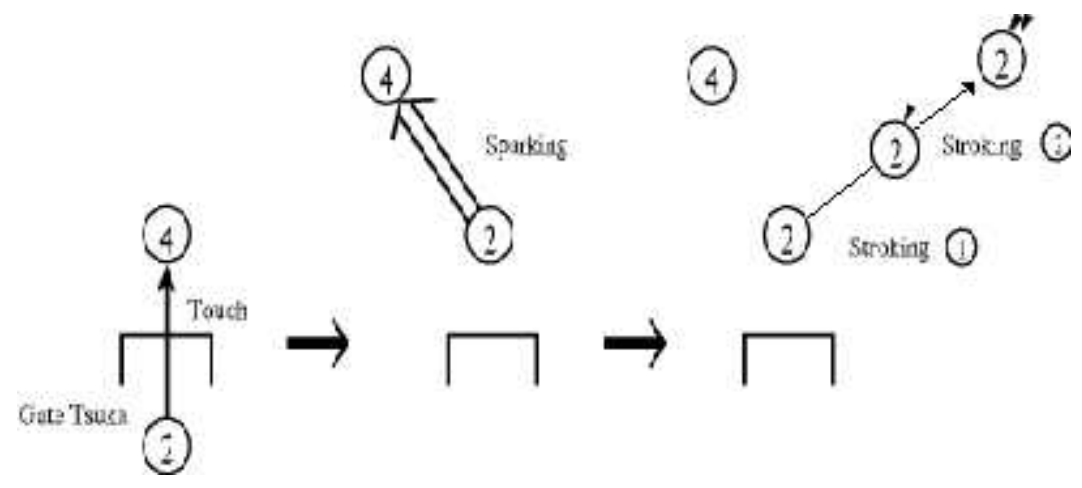

Gambar 13. Gate Tsuka

(Sumber: http://gateball.wordpress.com/cara-main/)

Bila bola yang dipukul mampu mengenai dua bola sekaligus, maka setelah melakukan dua kali sparking, bola tersebut mempunyai dua kali kesempatan untuk memukul berikutnya. Ini disebut double touh. 


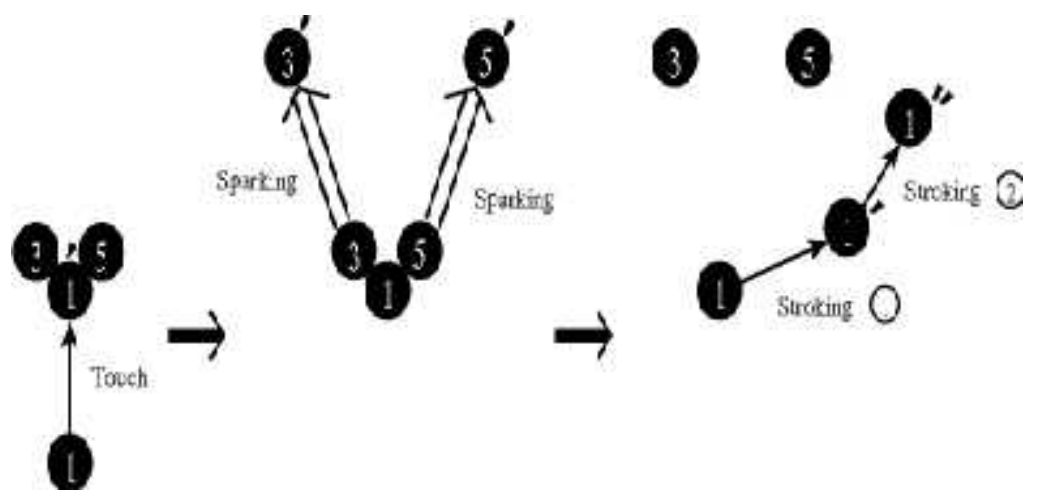

Gambar 14. Double Touch

(Sumber: http://gateball.wordpress.com/cara-main/)

\section{OLAHRAGA GATEBALL BAGI USIA LANJUT}

Usia lanjut adalah mereka yang berusia 55 tahun ke atas (Emma S. Wirakusumah, 2002: 5). Mereka yang telah memasuki usia lanjut akan mengalami penurunan fungsi organ yang dapat berpengaruh terhadap kemampuan melakukan aktivitas kerja. Hal ini terjadi pula pada organ paru, yang mengalami penurunan fungsi akibat berkurangnya elastisitas serabut otot yang mempertahankan bronkiolus tetap terbuka (Emma S. Wirakusumah, 2002:27).

Meningkatnya pertumbuhan orang usia lanjut di Indonesia dipengaruhi beberapa hal antara lain ekonomi, kesehatan, dan pendidikan. Pemahaman tentang gaya hidup sehat adalah faktor utama mengapa jumlah usia lanjut di Indonesia setiap tahun semakin meningkat. Salah satu hal tersebut adalah melakukan aktivitas seperti olahraga, menyalurkan hobi, dan kerja ringan. Khusus untuk olahraga, melakukan olahraga secara teratur bagi usia lanjut dapat memberikan dampak yang sangat positif bagi kesehatan tubuh. Salah satu olahraga tersebut adalah gateball dengan level menengah. Gateball memiliki banyak keunggulan salah satunya mengenai variasi suasana/lingkungan, dan gateball merupakan olahraga yang menggunakan alat yakni stick sebagai pemukul bola.

Pada usia lanjut terjadi penurunan masa otot serta kekuatannya, laju denyut jantung maksimal, toleransi latihan, kapasitas aerobik dan terjadinya peningkatan lemak tubuh sehingga seseorang dengan aktivitas fisik rendah mempunyai resiko yang lebih tinggi menghadapi kematian lebih awal. Kondisi fisik seseorang terkait erat dengan kesehatan dan kebugaran jasmani. Salah satu cara untuk mendapatkan kondisi fisik yang baik adalah melalui kegiatan olahraga yang teratur dan sesuai dengan keadaan tubuh tiap individu. Sebagaimana yang dikemukakan oleh Kosasih (1993: 21), bahwa:

Olahraga merupakan alat ampuh untuk pembentukan fisik dan mental bangsa. Dengan sering berolahraga, maka aktivitas sehari-hari juga akan terasa ringan saat melakukannya. Target dalam melakukan suatu aktivitas atau kegiatan adalah mencapai kepuasan tertinggi. 


\section{MEDIKORA Vol. VIII, No 2 April 2012}

Sasaran latihan fisik untuk usia lanjut adalah daya tahan kardiovaskuler, kekuatan otot dan daya tahan otot, salah satu contohnya adalah latihan gateball. Dengan latihan gateball, maka kaum usia lanjut diharapkan dapat memelihara kesehatan dan kebugaran jasmaninya. Usia lanjut yang tetap aktif juga dapat membangkitkan rasa kemampuan dan rasa percaya diri mereka untuk menunjang hidup sehat. Penelitian yang dilakukan oleh ZHAO Zhixiang1, XU Zhonghua1, XU Min2 (2009: 1) dengan mengambil subjek 122 orang tua yang dibagi dalam kelompok latihan (62 bermain gateball) dan kelompok kontrol (60 tidak pernah melakukan olahraga) menunjukkan bahwa latihan gateball dapat meningkatkan tingkat kebugaran fisik dan komposisi tubuh dari orang tua, serta dapat memainkan peranan penting dalam meningkatkan fungsi pernafasan.

Menurut Djoko Pekik Irianto (2000: 13) bahwa salah satu keberhasilan mencapai kebugaran ditentukan oleh takaran latihan yang dijabarkan dalam konsep FIT (Frekuensi, Intensitas, dan Time). Frekuensi adalah banyaknya unit latihan persatuan waktu, dalam meningkatkan kebugaran diperlukan latihan 3-5 kali per minggu. Olahraga gateball yang sering dilakukan oleh para usia lanjut biasanya dilakukan 3 kali per minggu. Intensitas adalah kualitas yang menunjukkan berat ringannya latihan, besarnya intensitas tergantung kepada jenis dan tujuan latihan. Oleh karena gateball termasuk olahraga ringan, maka intensitas yang diperlukan antara 60-75\% detak jantung maksimal. Time adalah waktu yang diperlukan setiap kali berlatih. Setiap kali berlatih dalam satu game, gateball memerlukan waktu 30 menit.

Secara alami, gateball bukan permainan berat, dan dapat dilakukan dalam gerakan lambat dan lembut. Namun, ketika ditanya mengapa mereka bermain gateball, mereka akan menjawab bahwa itu membuat mereka dalam kondisi fisik dan mental yang baik (Eva Tsai, Lena Fung, dan Pinky Tso, 2005). Olahraga gateball termasuk aman karena tidak ada kontak badan langsung. Gateball menyehatkan jasmani karena dilaksanakan di tempat terbuka, juga memperkaya rohani karena melatih cara komunikasi dan berpikir strategi. Bagi usia lanjut, tidak memerlukan tenaga yang berlebihan (http://gateballplnbali.blogspot.com/). Olahraga yang mengharuskan pemainnya banyak berjalan dan membungkuk ini sepintas mirip golf. Tapi, gateball bukanlah golf, karena bola tak dimasukkan ke lubang di tanah lapang, melainkan ke tiga gawang kecil berupa tonggak kecil. Olahraga yang menuntut keterampilan dan ketahanan stamina tubuh ini membutuhkan bola yang terbuat dari plat tipis. Ketrampilan tersebut yaitu memukul bola dengan dilakukan berulang-ulang sehingga bola bisa masuk dalam gawang. Dari ketrampilan memukul bola, usia lanjut secara otomatis akan terlatih untuk daya tahan otot bagian lengannya. Sedangkan untuk daya tahan otot bagian kaki pada 


\section{MEDIKORA Vol. VIII, No 2 April 2012}

permainan gateball dapat dilakukan saat pemain melakukan posisi stance (cara berdiri) yang tepat. Posisi stance yang baik diperlukan daya tahan otot kaki yang bagus juga, sehingga akan tercapai posisi berdiri yang kuat dan stabil.

Olah raga gateball termasuk olahraga yang sederhana, namun bermanfaat luar biasa. Penelitian yang dilakukan oleh Min Dong Choi pada wanita usia lanjut lebih dari 60 tahun berjumlah 160 orang yang dibagi menjadi kelompok latihan dan kelompok kontrol menyebutkan bahwa faktor kekuatan, kardiorespirasi, daya tahan otot, dan koordinasi dapat ditingkatkan melalui latihan gateball, terlihat pada kelompok latihan terjadi peningkatan yang lebih baik (Min Dong Choi, 2007: 209). Dengan melakukan olahraga gateball dapat melatih otot-otot kaki serta sendi, kedua organ ini merupakan organ paling rentan pada orang tua sehingga jika tidak sering-sering digerakan bisa mengalami kaku atau malah radang. Olahraga gateball dilaksanakan selama 30 menit dan 3 kali dalam seminggu secara teratur dan terukur. Oleh karena latihan/permainan gateball dilakukan dengan jalan kaki dan memukul bola selama 30 menit dalam satu game, maka latihan ini juga menggunakan energi aerob. Latihan aerob memiliki manfaat besar pada jantung, kesehatan tulang, dan pembuluh darah. Latihan aerob juga memberi manfaat positif pada otak. Latihan aerob pada otak berpengaruh positif pada kemampuan kognitif. Meningkatnya proses kognitif ditandai dengan meningkatnya memori. Selain itu, pemeliharaan aliran darah ke otak dan jantung adalah tugas yang sangat kritis dari sistem kardiovaskuler (Triawati Prihatsari Purwanto, http://harianjoglosemar.com/berita/olahraga-tingkatkan-kualitas-hidup-usia lanjut-).

Olahraga gateball dapat menjadi program kegiatan olahraga rutin yang dapat dilakukan di klub usia lanjut atau di rumah dalam lingkungan masyarakat. Dengan bermain gateball, orang tua percaya bahwa mereka dapat menunda secara lambat proses terjadinya penuaan (John W. Traphagan, 1998: 169). Olahraga gateball dilakukan dengan senang hati untuk memperoleh hasil latihan yang lebih baik yaitu kebugaran tubuh dan kebugaran mental seperti usia lanjut merasa berbahagia, senantiasa bergembira, bisa tidur lebih nyenyak, pikiran tetap segar.

\section{KESIMPULAN}

Sehat tidak hanya milik usia muda, saat usia senja kesehatan juga harus dijaga. Olahraga secara teratur bagi usia lanjut dapat memberikan dampak yang sangat positif bagi kesehatan tubuh. Dengan olahraga gateball, kaum usia lanjut dapat memelihara kesehatan dan kebugaran jasmaninya seperti daya tahan otot lengan, daya tahan otot kaki, koordinasi, serta daya tahan aerobik (daya tahan paru jantung). Olahraga gateball dapat menjadi program 


\section{MEDIKORA Vol. VIII, No 2 April 2012}

kegiatan olahraga rutin yang dapat dilakukan di klub usia lanjut atau di rumah dalam lingkungan masyarakat.

\section{DAFTAR PUSTAKA}

Djoko Pekik Irianto. (2000). Panduan Latihan Kebugaran (yang Efektif dan Aman). Yogyakarta: Lukman Offset

Emma S. Wirakusumah. (2002). Tetap Bugar di Usia Lanjut . Jakarta: Trubus Agriwidya

Eva Tsai, Lena Fung, and Pinky Tso. (2005). Gateball as a Leisure Activity: Satisfaction Derived. Hong Kong Baptist University.

John W. Traphagan. (1998). Reasons for Gateball Participation Among Older Japanese. Journal of Cross-Cultural Gerontology 13: 159-175. Netherlands: Kluwer Academic Publishers

Kosasih, Engkos. (1993). Olahraga dan Program Latihan. Jakarta : Akademika Presindo.

Min Dong Choi. (2007). A Characteristic of Motor Ability in the Elderly Women Performing Gateball. The Korean Journal of Growth and Development, Vol. 15, No. 3, pp. 209217. Kyungsung University.

Ruslan Burhani. Gateball Olahraga Unik Tanpa Batas Umur dan Gender. http://www.antaratv.com /berita/299772/gateball-olah-raga-unik-tanpa-batas-umur-dan-gender, diakses tanggal 12 Maret 2012.

Suryanto. (2011). Gateball. Jakarta: PERGATSI.

Triawati Prihatsari Purwanto. Olahraga Tingkatkan Kualitas Hidup Usia Lanjut. http://harianjoglosemar.com/berita/olahraga-tingkatkan-kualitas-hidup-usia lanjut38397.html?page=25, diakses tanggal 08 Maret 2012.

Yuda Turana. (2011). Sehat di Usia Lanjut. http://www.medikaholistik.com/medika.html? xmodule=document_detail\&xid=226\&ts=1332329220\&qs=health, diakses tanggal 16 Maret 2012.

ZHAO Zhixiang1, XU Zhonghua1, XU Min2. (2009). The Research Into the Effect of Gateball Exercise on the Physical Fitness Level of Elderly Male. Journal of Sports and Science. China: Bimonthly.

Yudhine. (2009). Bola. http://gateball.wordpress.com/equipment/bola-2/, diakses tanggal 12 Maret 2012. Bali Gateball Community.

. (2009). Cara main. http://gateball.wordpress.com/cara-main/, diakses tanggal 13 Maret 2012. Bali Gateball Community.

(2009). Gate. http://gateball.wordpress.com/equipment/gate/, diakses tanggal 12 Maret. Bali Gateball Community. 
(2009). Lapangan Gateball. http:/gateball.wordpress.com/equipment/lapangan/, diakses tanggal 09 Maret 2012. Bali Gateball Community.

. (2009). Pole. http://gateball.wordpress.com/equipment/pole/, diakses tanggal 13 Maret 2012. Bali Gateball Community.

(2009). Sejarah Gateball. http://gateball.wordpress.com/history/, diakses tanggal 08 Maret 2012. Bali Gateball Community.

. (2009). Tongkat Pemukul. http://gateball.wordpress.com/equipment/tongkatpemukul/, diakses tanggal 09 Maret 2012. Bali Gateball Community.

. (2009). Temukan Keharmonisan dalam Gateball . http://gateballplnbali. blogspot.com/2011/03/temukan-keharmonisan-dalam-gateball.html, diakses tanggal 13 Maret 2012. Bali Gateball Community. 